GLOBAL JOURNAL OF AGRICULTURAL SCIENCES VOL. 19, 2020: 11-15

COPYRIGHTC BACHUDO SCIENCE CO. LTD PRINTED IN NIGERIA ISSN 1596-2903 www.globaljournalseries.com, Email: info@globaljournalseries.com

\title{
FACTORS AFFECTING ENTREPRENEURSHIP DEVELOPMENT AMONG THE FOOD MARKETERS IN ILORIN METROPOLIS, KWARA STATE, NIGERIA.
}

IFABIYI J. O., BANJOKO I. K., AHMED S. A., LAWAL S. W., ISIAKAM. A. AND AWARUN O.

(Received 16 July 2019; Revision Accepted 14 August 2019)

\begin{abstract}
S
The study assessed the factors affecting entrepreneurship development among Food Marketers in llorin Metropolis, Kwara State, Nigeria. One hundred and ten respondents were randomly selected in four markets in llorin. The data was analyzed using frequency count, percentage, mean and Pearson Product Moment Correlation. The result reveals that mean age of the respondents was 30.5 years and about $58.2 \%$ were female. Record keeping skills (mean score $=2.42$ ) was the highest ranked entrepreneurial information needs of the respondents while lack of start-up capital (mean score $=2.40$ ) was the most severe factor affecting entrepreneurial activities of food marketers. There is a weak positive significant relationship between the entrepreneurial information needs and factors affecting entrepreneurial development of the respondents $(r=0.407, p=0.0001)$. The study recommends that there should be provision of training on entrepreneurial skills based on the identified areas of needs and there should be provision of credit facilities to the food marketers as these will enhance their productivity.
\end{abstract}

KEYWORDS: Entrepreneurial Development, Factors, Information Needs, Food Marketers, Ilorin Metropolis.

\section{INTRODUCTION}

An entrepreneur is a person who starts a business, or businesses, taking on financial risk in the hope of profit. Entrepreneurship is an activity that involves discovering, evaluating and exploiting opportunities in order to introduce products, services, methods, processes, and new materials (Sabuhilaki, 2016). Entrepreneurship is the application of energy for initiating and building an enterprise (Mishra, El-Osta \& Shaik 2010). The term entrepreneurship is used to describe the dynamic process of creating incremental wealth (Shailesh, Gyanendra \& Yadav 2013). Entrepreneurship is actually concerned with creating opportunities and meeting the needs of individuals or customers. Food marketer is a person that deals with food in the market. Food marketers promotes or sells food stuffs or food products in the market. Food marketers makes food available to the consumers in the market.

According to Owoade, (2014) entrepreneurs through their active participation in the food and agricultural sector would strongly impacts food security, industrialization efforts, quality of life, economic growth, and political stability and, to a certain extent, a nation's position in international relations and trade.
Development of entrepreneurship skills of food marketers will enhance their productivity, open up new business opportunities, improve the Nigerian economy and reduce the high rate of unemployment in Nigeria. This is important because agriculture is an effective strategy or tool to alleviate hunger and poverty as it has huge and diverse potentials that can not only transform the national economy but also immensely reduce the high rate of unemployment in the country (Amungwa \& Baye, 2014). Provision of entrepreneurial skills and financial opportunities to farmers and food marketers in Nigeria will help develop the Nigerian economy as sustainable development can only be achieved in Nigeria if there is food and nutritional security in the country.

According to Jancikova (2004), the factors affecting entrepreneurial activities are persistence factor, organizational factor, finance, education, personal autonomy, previous experience, creativity, sense of accomplishment and internal control. Also, poor management practices, low entrepreneurial skills, lack of relevant educational background and business exposure are the constraints of agricultural entrepreneurship in Nigeria (Chibundu, 2006). Several studies have been conducted in Nigeria on entrepreneurship. Nwibo \&

Ifabiyi J. O., Department of Agricultural Extension and Rural Development, University of Ilorin, Nigeria.

Banjoko I. K., Department of Agricultural Extension and Rural Development, University of Ilorin, Nigeria.

Ahmed S. A., Department of Agricultural Technology, Kwara State Polytechnic, Ilorin, Nigeria.

Lawal S. W., Department of Agricultural Technology, Kwara State Polytechnic, Ilorin, Nigeria.

Isiaka M. A., Agricultural and Rural Management Training Institute, Ilorin Ajase-Ipo High way, Kwara State, Nigeria.

Awarun O., Department of Sociology, Kogi State University, Anyigba, Nigeria 
Okorie (2013) examined the constraints to entrepreneurship among investors in South-east Nigeria and Kagbu (2018) also examined the constraints of women farmers' entrepreneurial development in Nasarawa State, Nigeria. However, there is dearth of information on the factors affecting entrepreneurial development among food marketers in kwara State. This creates a great lacuna in knowledge and this is the gap this study seeks to fill. It was on this note that this study sought to determine the factors affecting the entrepreneurial development among the food marketers in Ilorin metropolis, Kwara State.

The specific objectives were to;

(i) describe the socio-economic characteristics of the respondents.

(ii) determine the entrepreneurial information needs of the respondents.

(iii) identify the perceived factors affecting entrepreneurial development among the food marketers.

The Hypothesis of the study were stated in null form as: $\mathrm{HO}_{1}$ : There is no significant relationship between entrepreneurial information needs and the factors affecting the entrepreneurial development of food marketers in Ilorin Metropolis.

\section{METHODOLOGY}

The study was conducted in Ilorin Metropolis, Kwara State, Nigeria. Ilorin is the capital of kwara State, Nigeria. llorin is the most populated city in Kwara State. A two-stage sampling procedure was used for the study. The first stage involved a random selection off our markets in Ilorin metropolis. The markets are Oja-oba market, Ipata market, Oja-tuntun market and kulende market. The second stage involved a purposive selection of one hundred and ten respondents across the four markets. In Oja-oba market 30 respondents were selected, Ipata market 30 respondents were selected, in Oja-tuntun market 30 respondents were selected and in Kulende market 20 respondents were selected making a total of 110 respondents. To determine the entrepreneurial information needs of the respondents. Respondents were provided with the list of 16 possible entrepreneurial information need areas. A three-point Likert-typed scale was used, scores was assigned as follows: Not Needed=1, Moderately Needed=2 and Highly Needed=3. To identify the factors affecting entrepreneurial development, respondents were provided with the list of 16 possible factors affecting entrepreneurial development. A three-point Likert-typed scale of Not a factor=1, Not serious=2, Serious $=3$ was used. Descriptive statistics such as frequency counts, percentage and mean score were used to analyse the finding of the study. Pearson Product Moment Correlation (PPMC) was used to test the hypothesis of the study. The SPSS statistical package 22 was used to analysed the data of the study.

\section{RESULTS AND DISCUSSION}

The Socio-economic Characteristics

The result in Table 1 reveals that more than half $(58.2 \%)$ of the respondents were female and about $41.8 \%$ were male. This result indicates that both male and female are involved in food marketing. The average age of the respondents was 30.5 years. This denotes that the respondents were in economic active age bracket. This result is in contrast with the findings of Olowa and Olowa (2015) who reported that the average age of people in agri-business in Lagos State was 42.1 years. The result in Table 1 reveals that about $47.0 \%$ of the respondents were single while about $40.0 \%$ were married. This indicated that higher percentage of the respondents does not have marital responsibility. The result in Table 1 reveals that about $40.9 \%$ of the respondents had tertiary education. The average monthly income of the respondents was $50,136.13 \mathrm{Naira}$. This indicates that food marketing is a viable means of livelihoods as the average monthly income of the respondents is above the new national minimum wage of 30,000 naira in Nigeria. This result is contrary to the findings of Kagbu (2018) who reported that average monthly income of women farmers in Nasarawa State, Nigeria was 17,396.62 Naira. The average years of experience of the respondents was 5.7 years. The result in Table 1 further reveals that about $30.0 \%$ of the respondents were into meat and fish business and about $21.8 \%$ were into beverages and package food business in the study area. 
Table 1: SOCIO-ECONOMIC CHARACTERISTICS ( $N=110)$

\begin{tabular}{|c|c|c|c|}
\hline Variable & \begin{tabular}{|l|} 
Frequency \\
\end{tabular} & Percentage & Mean \\
\hline $\begin{array}{l}\text { 1.Gender } \\
\text { Male } \\
\text { Female }\end{array}$ & $\begin{array}{l}46 \\
64\end{array}$ & $\begin{array}{l}41.8 \\
58.2\end{array}$ & \\
\hline $\begin{array}{l}\text { 2. Age } \\
\leq 20 \\
21-30 \\
31-40 \\
\geq 41\end{array}$ & $\begin{array}{l}3 \\
66 \\
34 \\
7\end{array}$ & $\begin{array}{l}2.7 \\
60.0 \\
31.0 \\
6.3\end{array}$ & 30.5 years \\
\hline $\begin{array}{l}\text { 3. Marital status } \\
\text { Single } \\
\text { Married } \\
\text { Separated } \\
\text { Widowed } \\
\text { Divorced }\end{array}$ & $\begin{array}{l}52 \\
44 \\
8 \\
5 \\
1 \\
\end{array}$ & $\begin{array}{l}47.0 \\
40.0 \\
7.3 \\
4.5 \\
0.91\end{array}$ & \\
\hline $\begin{array}{l}\text { 4. Educational Status } \\
\text { Non-Formal } \\
\text { Primary } \\
\text { Secondary } \\
\text { Tertiary }\end{array}$ & $\begin{array}{l}12 \\
15 \\
38 \\
45 \\
\end{array}$ & $\begin{array}{l}10.9 \\
13.6 \\
34.5 \\
40.9 \\
\end{array}$ & \\
\hline $\begin{array}{l}\text { 5.Monthly Income (Naira) } \\
\geq 50,000 \\
\leq 50,000\end{array}$ & $\begin{array}{l}82 \\
28\end{array}$ & $\begin{array}{l}74.5 \\
25.5\end{array}$ & $\begin{array}{l}50136.13 \\
\text { Naira }\end{array}$ \\
\hline $\begin{array}{l}\text { 6. Years of experience } \\
\leq 5 \\
5-10 \\
\geq 11\end{array}$ & $\begin{array}{l}73 \\
25 \\
12\end{array}$ & $\begin{array}{l}66.36 \\
22.73 \\
10.91\end{array}$ & 5.7 years \\
\hline $\begin{array}{l}\text { 7. Type of Food Marketing Enter } \\
\text { Cooked food vendor } \\
\text { Beverages/Package food vendor } \\
\text { Meat/Fish seller } \\
\text { Fruit seller } \\
\text { Raw/uncooked food vendor } \\
\text { Other }\end{array}$ & $\begin{array}{l}14 \\
24 \\
33 \\
15 \\
19 \\
5\end{array}$ & $\begin{array}{l}12.7 \\
21.8 \\
30.0 \\
13.6 \\
17.4 \\
4.5\end{array}$ & \\
\hline
\end{tabular}

\section{Entrepreneurial Information Needs}

The result in Table 2 reveals that the highest ranked entrepreneurial information needs of the respondents was record keeping skills (mean score $=2.42$ ), the second ranked entrepreneurial information needs was risk taking skills (mean score $=2.32$ ), The third ranked entrepreneurial information needs was time management skills (mean score $=2.30$ ), goal setting skills (mean score $=2.28$ ), decision making skills (mean score $=2.22$ ), product branding and packaging skills (mean score $=2.21$ ), customer relation skills (mean score $=2.20$ ), business plan, proposal writing and marketing skills ( mean score $=2.17$ ), value addition initiative (mean score $=2.11$ ) and persuasive and persistent skills (mean score $=2.03$ ). This indicates that the food marketers required more information as there are gaps in their current knowledge on entrepreneurial skills. This result is in agreement with the findings of Owoade, Omogoye and Olaniyan (2011) who reported that the entrepreneurs needs motivation skills, credit acquisition skills, interpersonal relationship skills, social network and interaction skill. 
Table 2: The Entrepreneurial Information Needs of the Respondents.

\begin{tabular}{|l|l|l|l|l|}
\hline Entrepreneurial Information Needs & Mean & S.D & Rank & Remark \\
\hline 1. Goal setting skills & $2.28^{* *}$ & 0.608 & 4 & Highly Needed \\
\hline 2. Risk taking skills & $2.32^{* *}$ & 0.651 & 2 & Highly Needed \\
\hline 3. Efficiency and quality skills & $1.98^{*}$ & 0.691 & 12 & LowlyNeeded \\
\hline 4. Credit acquisition skills & $1.94^{*}$ & 0.694 & 16 & LowlyNeeded \\
\hline 5. customer relation skills & $2.20^{* *}$ & 0.727 & 7 & Highly Needed \\
\hline 6. Record keeping skills & $2.42^{* *}$ & 0.721 & 1 & Highly Needed \\
\hline 7. Time management skills & $2.30^{* *}$ & 0.761 & 3 & Highly Needed \\
\hline 8. Decision making skills & $2.22^{* *}$ & 0.645 & 5 & Highly Needed \\
\hline 9. Persuasive and persistent skills & $2.03^{* *}$ & 0.729 & 11 & Highly Needed \\
\hline 10. Networking skills & $1.97^{*}$ & 0.723 & 13 & LowlyNeeded \\
\hline 11. Business plan/proposal writing & $2.17^{* *}$ & 0.702 & 8 & Highly Needed \\
\hline 12. Product packaging/branding skills & $2.21^{* *}$ & 0.679 & 6 & Highly Needed \\
\hline 13.Information and Communication Technology skills & $1.95^{*}$ & 0.613 & 15 & LowlyNeeded \\
\hline 14. Marketing skills & $2.17^{* *}$ & 0.734 & 8 & Highly Needed \\
\hline 15. Business registration information & $1.97^{*}$ & 0.715 & 14 & LowlyNeeded \\
\hline 16.Value addition initiatives & $2.11^{* *}$ & 0.726 & 10 & Highly Needed \\
\hline
\end{tabular}

Note: Likert scale - Not Needed=1, Moderately Needed=2, Highly Needed=3. Decision rule: $(1+2+3=6 / 3=2.0)$. Mean score $\geq 2.00$ = Highly Needed; $\leq 2.00=$ Lowly Needed.

The Factors Affecting Entrepreneurial Development of Food Marketers

The result in Table 3 reveals that the most severe factor affecting entrepreneurial activities among food marketers was lack of startup capital (mean score $=2.40$ ), the second ranked factor affecting entrepreneurial activities was poor attitude of the society to food marketers (mean score $=2.34$ ), ranked third was cumbersome procedure for credit acquisition (mean score $=2.21$ ), long distance to the rural farms and markets (mean score $=2.20$ ) and lack of labour (mean score $=2.17$ ). This result reveals that food marketers were constrained by poor infrastructures, lack of market opportunity, lack of access to finance and enabling environment and managerial skills. These factors indicated that there are enormous challenges facing food marketers. This result is in agreement with the findings of Olowa and Olowa (2015) who reported that the factors affecting entrepreneurial activities are economic, social, cultural, marketing and training factors.

Table 3: The Perceived Factors affecting Entrepreneurial Development

\begin{tabular}{|c|c|c|c|c|}
\hline Factors & Mean & S D & Rank & Remark \\
\hline 1.Lack of start-up capital & $2.40^{\star *}$ & 0.726 & 1 & Highly Severe \\
\hline 2.Poor infrastructural facilities & $2.15^{\star *}$ & 0.715 & 6 & Highly Severe \\
\hline 3.Unavailability of machine /equipment & $1.96^{*}$ & 0.735 & 14 & Less Severe \\
\hline 4.Business registration problem & $1.99^{*}$ & 0.711 & 13 & Less Severe \\
\hline 5. High cost of rents/inputs & $2.10^{\star *}$ & 0.647 & 8 & Highly Severe \\
\hline 6.Low patronage of locally made good & $2.03^{* *}$ & 0.723 & 10 & Highly Severe \\
\hline 7. Political instability/civil interest & $1.93^{*}$ & 0.646 & 16 & Less Severe \\
\hline 8. Lack of adequate information & $2.10^{* *}$ & 0.805 & 8 & Highly Severe \\
\hline 9. Family commitment & $2.01^{* \star}$ & 0.677 & 11 & Highly Severe \\
\hline 10.Poor family background & $1.95^{*}$ & 0.683 & 15 & Less Severe \\
\hline 11. Inadequate experience and exposure entrepreneurial activities & $2.00^{* *}$ & 0.691 & 12 & Highly Severe \\
\hline 12.Cumbersome procedure for credit facilities & $2.21^{* *}$ & 0.664 & 3 & Highly Severe \\
\hline 13. Scarcity of labour & $2.17^{* *}$ & 0.709 & 5 & Highly Severe \\
\hline 14. High cost of labour & $2.11^{* *}$ & 0.729 & 7 & Highly Severe \\
\hline 15. Long distance to rural farms and markets & $2.20^{\star *}$ & 0.734 & 4 & Highly Severe \\
\hline 16. Poor attitude of the society toward food marketers & $2.34^{* *}$ & 0.679 & 2 & Highly Severe \\
\hline
\end{tabular}

Note: Likert-typed scale of Not a factor=1, Not serious $=2$, Serious=3, Decision rule: $(1+2+3=6 / 3=2.0)$. Mean score $\geq 2.00=$ Highly Severe Factor ${ }^{* *} ; \mathbf{2 . 0 0}=$ Less Severe Factor ${ }^{*}$.

\section{TESTING OF HYPOTHESIS:}

$\mathrm{HO}_{1}$ : There is no significant relationship between entrepreneurial information needs and the factors affecting the entrepreneurial development of food marketers in Ilorin Metropolis.

The result in Table 4 reveals that there is a weak positive significant relationship between the entrepreneurial information needs and factors affecting entrepreneurial development $(r=0.470, p=0.001)$ at $1 \%$ level of significance. This denotes that the higher the entrepreneurial information needs, the higher the factors affecting entrepreneurial activities of the marketers. This further indicates that the higher the severity of the factors affecting entrepreneurial activities, the more the 
food marketers would seek more information on their entrepreneurial activities. The implication of the weak positive correlation is that as one variable increases, there is a lower likelihood of an increase in the second variable.

Table 4: The Result of Correlation of Entrepreneurial Information needs and the Factors affecting the Entrepreneurial Development of Food Marketers

\begin{tabular}{|c|c|c|}
\hline & $\begin{array}{l}\text { Factors affecting Entrepreneuria } \\
\text { Development }\end{array}$ & Entrepreneurial information Needs \\
\hline \multirow{3}{*}{ 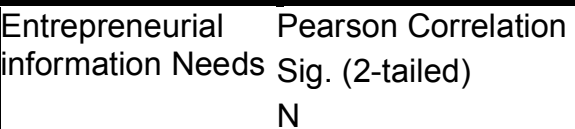 } & 1 & $0.470^{*}$ \\
\hline & & 0.000 \\
\hline & 110 & 110 \\
\hline \multirow{3}{*}{$\begin{array}{ll}\text { Factors affecting } & \text { Pearson Correlation } \\
\text { Entrepreneurial } & \text { Sig. (2-tailed) } \\
\text { Development } & \mathrm{N} \\
\end{array}$} & 0.470 & 1 \\
\hline & 0.000 & \\
\hline & 110 & 110 \\
\hline
\end{tabular}

Note $:{ }^{* *}$. Correlation is significant at the 0.01 level (2-tailed).

\section{CONCLUSION}

Based on the findings of this study, the study concluded that the average age of the respondents was 30.5 years, the average monthly income of the respondents was $50,136.13$ Naira, the highest ranked entrepreneurial information need was record keeping skills and lack of start-up capital was the most severe factor affecting entrepreneurial development among the food marketers.

\section{RECOMMENDATION}

In order to develop entrepreneurial capacity of the food marketers in Nigeria, this study recommends that there should be provision of training on entrepreneurial skills based on the identified areas of needs and there should be provision of credit facilities to the food marketers as this will enhance their productivity.

\section{REFERENCES}

Amungwa F. A., and Baye F. M., 2014. Appraisal of the Agricultural Extension System. Asian Journal of Agricultural Extension Economics and Sociology 2(2): 530-543.

Chibundu, E., 2006 "Strategies for Nigerian SMEs to Grow Economy" an excerpt of interview with Nigerian Vanguard Newspaper, distributed by All Africa Global Media, (allafrica.com) available at http//blog.tmcnet.com/voipenterprise/tmcnet/strategies for NigerianSMEs-to-grow-economy prof-chibundu.asp, Accessed on 07/07/2019.

Jancikova, H., 2004. The Entrepreneurial Factor in Economic Growth. London: Macmillan. Organization Studies 20 (6): 1011-1033.

Kagbu J.H., 2018. Constraints of Women to Farmers' Entrepreneurial Development in Nasarawa State, Nigeria. Journal of Agricultural Extension, Vol. 22(1).
Mishra, A., H. El-Osta, H., and S. Shaik,2010. Succession Decisions in U. S. Family Farm Business. Journal of Agricultural and Resource Economics, Vol. 35, No.; pp. 133152.

Nwibo, S. U. and Okorie, A., 2013 Constraints to Entrepreneurship and Investment Decisions among Agribusiness Investors in Southeast, Nigeria. International Journal of Small Business and Entrepreneurship Research,1(4): 38-50.

Olowa O.W and Olowa O.A., 2015. Factors Affecting Entrepreneurship Development in Agribusiness Enterprises in Lagos State, Nigeria. Global Journal of Management and Business Research Volume 15 Issue 7. Version

Owoade, O.A., 2014. Nigerian Youths and Agropreneur Development: Turning Challenges into Opportunities. Yaba Journal of Management Studies; 9(1), 110-119.

Owoade, O.A., Omogoye, A. M., and Olaniyan, S. T., 2011 Sustainable Reforms towards Emergence of Agropreneurs; The Moulder, 3(2), 167-178. Oyo, Nigeria, 3(2),

Sabuhilaki B., 2016. Social Factors Affecting Entrepreneurship and Youth Employment. International Journal of Humanities and Cultural Studies. Vol 3, Issue 1.

Shailesh, K., Gyanendra, S and V. K., Yadav 2013. Factors Influencing Entrepreneurial Behaviour of Vegetable Growers; Indian Res. J. Ext. Edu. 13 (1). 